\title{
Irrigation Affects Landscape Establishment of Burford Holly, Pittosporum, and Sweet Viburnum
}

\author{
S.M. Scheiber ${ }^{1,2}$ \\ University of Florida, IFAS, Environmental Horticulture Department, MREC, \\ 2725 Binion Road, Apopka, FL 32703
}

E.F. Gilman ${ }^{3}$ and M. Paz ${ }^{4}$

University of Florida, IFAS, Environmental Horticulture Department, 2543

Fifield Hall, Gainesville, FL 32611

\author{
K.A. Moore ${ }^{5}$ \\ University of Florida, IFAS, Environmental Horticulture Department, \\ FLREC, 3205 College Avenue, Ft. Lauderdale, FL 33314
}

Additional index words. landscape irrigation, irrigation frequency, landscape water management, microirrigation, roots, Ilex cornuta 'Burfordii Nana', Pittosporum tobira 'Variegata', Viburnum odorotissimum

\begin{abstract}
Ilex cornuta Lindl. \& Paxt. 'Burfordii Nana' (dwarf burford holly), Pittosporum tobira [Dryand]. 'Variegata' (pittosporum), and Viburnum odorotissimum Ker Gawl. (sweet viburnum) were transplanted into field plots in an open-sided, clear polyethylenecovered shelter to evaluate growth, aesthetic quality, and establishment rates in response to 2-, 4-, or 7-d irrigation frequencies. Establishment was delayed 1 to 2 months for I. cornuta 'Burrford Nana' irrigated every $7 \mathrm{~d}$ compared with 2- and 4-d frequencies; however, growth and aesthetic quality were similar among treatments. Plants irrigated every $7 \mathrm{~d}$ also had higher cumulative water stress levels. Leaf area, shoot dry weight, and total biomass increased among $P$. tobira 'Variegata' and $V$. odorotissimum irrigated every 2 d. Pittosporum tobira 'Variegata' and $V$. odorotissimum irrigated every $2 \mathrm{~d}$ also had greater canopy size and root dry weight, respectively. Neither cumulative water stress nor establishment was affected by irrigation frequency for either species.
\end{abstract}

Water is the most limiting factor in establishing container-grown trees and shrubs in the landscape, and water stress is the number one cause of transplant failure (Barnett, 1986; Gilman et al., 1996). Irrigation and water management are important components of the urban landscape as demand for plants, population expansion, and increased housing starts have escalated concerns among water management officials that requests will exceed supply (Archer, 2002). Landscape water consumption is highly visible and provides a prime target for water restrictions and subsequent regulation (Salamone, 2002; Thayer, 1982). Imposing water restrictions during landscape establishment can be detrimental to plants that have not had adequate time to develop sufficient root systems to compensate for losses to evapotranspiration (Montague

Received for publication 3 Aug. 2006. Accepted for publication 30 Oct. 2006.

This work was supported by the Florida Agricultural Experiment Station and approved for publication.

${ }^{1}$ Assistant Professor.

${ }^{3}$ Professor.

${ }^{4}$ Biological Scientist.

${ }^{5}$ Associate Professor.

${ }^{2}$ To whom reprint requests should be addressed; e-mail scheiber@ufl.edu. et al., 2000). Because retail nurseries offer guarantees against plant death during the first year after purchase, plant death resulting from insufficient water for establishment can have a significant economic impact on the nursery industry.

Current recommendations and regulations in Florida vary by source and municipality and often do not correspond. Recommendations advise daily irrigation until established with establishment times increasing proportional to container size. References indicate standard 3-gallon containers commonly used in both residential and commercial landscape installations require 6 to 12 months to establish, yet recent trends within Florida have been toward the adoption of policies such as $60 \mathrm{~d}$ or less of daily irrigation for landscape establishment (Trenholm et al., 2002). Furthermore, irrigation recommendations and estimated establishment rates are based primarily on anecdotal observations of plant performance of mixed landscape plantings (Garcia-Navarro et al., 2004).

Many factors, including application frequency, are known to affect shrub establishment, yet there are no clear data on how long it takes for a shrub to become established. Daily irrigation of Ilex cornuta 'Burford Nana' during establishment significantly increased shoot number, shoot-to-root ratios, and the percentage of roots originating from the top half of the root ball. Less frequent irrigation promoted deeper rooting but decreased shoot growth (Gilman et al., 1996). No differences in mortality rates or aesthetic quality were found between irrigation frequencies of Ceanothus griseus (Trelease) McMinn var. horizontalis 'Santa Ana', Rhamnus californica Eschscholtz, R. californica 'Eve Case', and Photinia $\times$ fraseri Dress provided the total volume of water applied was equal and within the tolerance of the species (Paine et al., 1992). Establishment times for various tree species have been determined based on leaf gas exchange, water potential, and growth parameters; however, the methodology has not been applied for determination of shrub establishment rates (Beeson and Gilman, 1992; Montague et al., 2000; Watson, 1985). Given the discrepancies between irrigation regulations and recommendations and a lack of viable knowledge regarding shrub establishment rates, the objectives of this study were to determine 1) the effects of irrigation frequency on establishment, growth, and aesthetic quality of Ilex cornuta 'Burfordii Nana', Pittosporum tobira 'Variegata', and Viburnum odorotissimum and 2) quantify the time until establishment.

\section{Materials and Methods}

Ilex cornuta 'Burfordii Nana', Pittosporum tobira 'Variegata', and Viburnum odorotissimum obtained from a commercial nursery in 11.4-L containers were transplanted on 11 Aug. 2004 into an excessively drained fine sand (Apopka fine sand series) under an open-sided clear polyethylenecovered rainout shelter $\approx 4 \mathrm{~m}$ tall. Species were selected to represent taxa with low, medium, and high water requirements, respectively. Classifications were based on plant water use efficiency estimates for containerized specimens grown under nursery production conditions and information garnered from a survey conducted among wholesale nursery growers regarding plant irrigation requirements (Beeson, 2000; Henley et al., 2000). Taxa were planted on $1.8-\mathrm{m}$ centers in $1.5-\mathrm{m}$ wide strips and mulched with 7.5 to $10 \mathrm{~cm}$ pine bark nuggets to a depth of $7.5 \mathrm{~cm}$ (Sunrise Landscape Supply, Orlando, Fla.). Areas between strips were covered with a single layer of black polypropylene ground cloth $(0.6 \mathrm{~m}$ wide; BWI Companies, Apopka, Fla.) to inhibit weed growth. Before transplant, soil under the shelter was saturated to a depth of $0.6 \mathrm{~m}$. To evaluate the effect of irrigation frequency on establishment rate and growth, each species was irrigated every 2, 4, or $7 \mathrm{~d}$ and received $9 \mathrm{~L}$ of water per plant per irrigation event. Each plant was irrigated with three bubbler emitters (Model Shrubbler $360^{\circ}$; Antelco, Longwood, Fla.) applying $3 \mathrm{~L}$ each. Each emitter was mounted $10.2 \mathrm{~cm}$ above ground level with one emitter located on the north and one on the south side of each plant, $15 \mathrm{~cm}$ from the outside of the root ball, and the third emitter positioned on the root ball. 
The Christiansen coefficient of uniformity was a minimum of 0.99 before planting (Haman et al., 1996). Irrigation of each bed was controlled as a separate zone using an automated irrigation time clock (Model Sterling 12; Superior Controls Co., Valencia, Calif.). Irrigations began at $0500 \mathrm{HR}$ and were completed by 0600 HR each day. Flow meters (Model C700TP; ABS, Ocala, Fla.) were installed for each zone to record irrigation volumes Monday through Friday. Weekend irrigation volumes were included in total volume recorded the next Monday.

On 13 May 2004, six replicates of each species were transplanted into a companion open field plot (Apopka fine sand series) to serve as control indicator plants for water potential measurement comparisons. Transplanting occurred 3 months before installation of rainout shelter plants to permit establishment. Plots were irrigated as previously described. Only one plant per species was used for water potential measurements on each sampling date.

Nutrition on each plot was managed with best management practices (Trenholm et al., 2002). Controlled-release fertilizer was uniformly broadcast in each bed area $30 \mathrm{~d}$ after transplanting at a standard rate of $0.91 \mathrm{~kg} \mathrm{~N} /$ $100 \mathrm{~m}^{2}$ of $12 \mathrm{~N}-0.9 \mathrm{P}-11.6 \mathrm{~K}$ Southern Landscape Fertilizer (LESCO, Sebring, Fla.).

Growth indices and biomass. Measurements of average canopy height, widest canopy width (width 1), and width perpendicular to the widest width (width 2) were recorded to calculate growth indices (growth index $=$ height $\times$ width $1 \times$ width 2 ). All plants were measured immediately after transplant, monthly, and at final harvest. The experiment was ended on 8 Feb. 2005 and plants immediately harvested. To calculate shoot-to-root ratios, shoots were severed at the soil line and dried at $65{ }^{\circ} \mathrm{C}$ until constant dry weight was obtained. To obtain new root dry weight, one-eighth segments of the soil volume outside of the root ball and extending beyond the longest root in each segment were removed from the north northeast (NNE) and south southwest (SSW) sides of each plant. Substrate or soil was removed from roots, and roots were dried as described for shoots. Dry weights of NNE and SSW segments were summed and multiplied by 4 to obtain total new root dry weight. At transplanting, a representative sample of three plant replications per species were measured and dried as described to obtain initial values. Average initial root dry weight in the root ball and total new root dry weight were summed to obtain an estimated total root dry weight for calculation of shoot-to-root ratios. Root lengths were determined by measuring the longest root extending from the center of the root ball in each harvested segment.

Stem water potential and leaf gas exchange measurements. Shoot water potential $\left(\Psi_{\mathrm{w}}\right)$ was measured monthly on all replicates of each species for each treatment beginning 8 weeks after transplanting (WAT). Measurements were made at predawn, midday, and dusk on the day before irrigation (stressed) and the day of irrigation (unstressed). Shoot water potential was determined with a pressure chamber (Model 3000; Soil Moisture Equipment Corp., Santa Barbara, Calif.) using compressed $\mathrm{N}$ with pressure increasing at a rate of $2.5 \mathrm{kPa} \cdot \mathrm{s}^{-2}$. Measurements were made on individual twigs ( $\approx 10 \mathrm{~cm}$ long). Cumulative daily water stress integrals $(\mathrm{S} \psi)$ were calculated as described by Schulze et al. (1980) and Beeson (1992). Area over the water potential curve was integrated and the absolute value taken for each species on each sampling date. $G_{\mathrm{S}}$ measurements were at $1000 \mathrm{HR}, 1300 \mathrm{HR}$, and $1600 \mathrm{HR}$ on the same sampling dates described for shoot water potential. Measurements were taken on two leaves on each plant during each sampling period with a steadystate porometer (LI-1600; LI-COR, Lincoln, Neb.).

Climatic data. Daily climatic data were obtained from the Florida Automated Weather Station (FAWN) located $50 \mathrm{~m}$ from the site. Photosynthetic photon flux $(P P F)$ was measured within the rainout shelter with a sunfleck ceptometer (Decagon Devices, Pullman, Wash.) and a $12 \%$ reduction in $P P F$ was noted.

Aesthetic quality. Landscape quality, based on aesthetic appearance, was rated monthly by three subjects on a scale of 1 (dead) to 5 (mounded, proportional form; dense; complete coverage, no dieback). Ratings were averaged across subjects.

Data analysis. The experiment was conducted as a randomized complete block design with four blocks of single plant replicates. Each block contained all three species and all three irrigation frequency combinations for a total of nine plants per block. Data were analyzed separately for all species. Growth data, consisting of final plant height, growth index, shoot dry weight, root dry weight, total biomass, and shoot-to-root ratio, were analyzed as a one-way analysis of variance with three irrigation frequencies and four replications. Root length and root dry weight were analyzed separately by quadrant as a $3 \times 2$ factorial with three irrigation frequencies and two quadrants. Landscape quality was analyzed using a one-way analysis of variance for each sampling period. Cumulative water stress integral values and $\mathrm{g}_{\mathrm{s}}$ were analyzed as repeated measures using a split plot design with irrigation frequency as the main plot and day as a subplot (Snedecor and Cochran, 1980). Each sampling date was analyzed separately. Where significant differences were indicated, mean separation was by Fisher protected least significance differences (Snedecor and Cochran, 1980). All analysis was conducted using SAS (version 8.1; SAS Institute, Cary, N.C.).

\section{Results and Discussion}

Growth and biomass. Survival was unaffected by irrigation frequency with the exception of $V$. odorotissimum. By 16 WAT, $50 \%$ of $V$. odorotissimum plants irrigated every $7 \mathrm{~d}$ were dead. No other plants of any species died.

For I. cornuta 'Burfordii Nana', irrigation frequency had no effect $(P>0.05)$ on final growth index, height, leaf area, total shoot and root dry weight, new shoot and root dry weight, total biomass, or shoot-to-root ratios. Bryla et al. (2003) reported similar results for Prunus persica (L.) Batsch 'Crimson Lady' irrigated at various frequencies with furrow or microjet irrigation. Two- and 4-d frequencies increased root extensions by $30 \%$ and $17 \%$, respectively, relative to plants irrigated every $7 \mathrm{~d}$ (Table 1 ). Root dry weight was greater $(P<0.01)$ in the northeast segment, $11.3 \mathrm{~g}$, than the southwest sector, $6.8 \mathrm{~g}$ (data not shown). Marshall and Gilman (2002) also found more root growth on the northeast side of red maples after transplant and suggested the response may be the result of shading from the canopy.

For P. tobira 'Variegata', final height, total root dry weight, new root dry weight, and shoot-to-root ratios were similar for all irrigation frequencies $(P>0.05$; data not shown). However, plants irrigated every $2 \mathrm{~d}$ had greater $(P<0.01)$ leaf area, shoot dry weight, biomass, and final growth index than plants irrigated every 4 or $7 \mathrm{~d}$ (Table 2). Growth increased by at least $42 \%$ and $52 \%$, dependent on parameter, if plants received irrigation every other day relative to applications every 4 or $7 \mathrm{~d}$, respectively. Root lengths were $36 \%$ and $50 \%$ greater $(P<$ $0.05)$, respectively, for $P$. tobira 'Variegata' receiving irrigation every $2 \mathrm{~d}$ compared with 4- and 7-d frequencies (Table 1).

Table 1. Mean root lengths for Ilex cornuta 'Burfordii Nana', Pittosporum tobira 'Variegata', and Viburnum odoratissimum irrigated at three frequencies $(2,4$, or $7 \mathrm{~d})$ over a 6 -month period during late summer to early spring in central Florida.

\begin{tabular}{lcc}
\hline Species & Irrigation frequency & $\begin{array}{c}\text { Root length } \\
(\mathrm{cm})^{\mathrm{z}}\end{array}$ \\
\hline Ilex cornuta 'Burford Nana' & 2-day & $45.56 \mathrm{a}^{\mathrm{yx}}$ \\
& 4-day & $41.06 \mathrm{a}$ \\
Pittosporum tobira 'Variegata' & 7-day & $35.00 \mathrm{~b}$ \\
& 2-day & $44.84 \mathrm{a}$ \\
Viburnum odorotissimum & 4-day & $33.08 \mathrm{~b}$ \\
& 7-day & $29.94 \mathrm{~b}$ \\
& 2-day & $52.13 \mathrm{a}$ \\
\end{tabular}

${ }^{\mathrm{z}}$ Root lengths were measured outside the root ball of the harvested segment.

${ }^{y}$ Means calculated from four single plant replicates.

${ }^{\mathrm{x}}$ Mean separations within column and species using Fisher protected LSD $(P<0.05)$. 
Table 2. Growth measurements for Pittosporum tobira 'Variegata' and Viburnum odoratissimum irrigated every 2, 4, or $7 \mathrm{~d}$ over a 6-month period during late summer to early spring in central Florida.

\begin{tabular}{|c|c|c|c|c|c|c|c|}
\hline Species & $\begin{array}{l}\text { Irrigation } \\
\text { frequency }\end{array}$ & Leaf area $\left(\mathrm{cm}^{2}\right)$ & Shoot dry wt. (g) & $\begin{array}{l}\text { New root } \\
\text { dry wt. }(\mathrm{g})\end{array}$ & $\begin{array}{l}\text { Total root } \\
\text { dry wt. (g) }\end{array}$ & Biomass (g) & Growth index $\mathrm{x}^{\mathrm{z}}\left(\mathrm{m}^{3}\right)$ \\
\hline & 4-day & $5696 \mathrm{~b}$ & $191.5 \mathrm{~b}$ & 17.79 & 72.79 & $264.3 \mathrm{~b}$ & $0.12 \mathrm{~b}$ \\
\hline & 7-day & $5256 \mathrm{~b}$ & $200.3 \mathrm{~b}$ & 8.21 & 52.86 & $253.2 \mathrm{~b}$ & $0.11 \mathrm{~b}$ \\
\hline \multirow{2}{*}{ Viburnum odorotissimum } & 4-day & $6488 \mathrm{ab}$ & $203.7 \mathrm{ab}$ & $50.67 \mathrm{~b}$ & $95.32 \mathrm{~b}$ & $299.0 \mathrm{ab}$ & 0.24 \\
\hline & 7-day & $1583 \mathrm{~b}$ & $84.9 \mathrm{~b}$ & $8.22 \mathrm{~b}$ & $63.22 \mathrm{~b}$ & $148.1 \mathrm{~b}$ & 0.13 \\
\hline
\end{tabular}

${ }^{\mathrm{z}}$ Growth index $=$ height $\times$ width $1 \times$ width 2 .

${ }^{\mathrm{y}}$ Means representative of four single plant replicates.

${ }^{\mathrm{x}}$ Mean separations within columns and species using Fisher protected LSD $(P=0.05)$.

${ }^{\mathrm{N}}$ Nonsignificant.

For $V$. odorotissimum, irrigation frequency did not affect final height, growth index, or shoot-to-root ratios $(P>0.05$; data not shown). However, leaf area, shoot dry weight, and total biomass were $(P<0.05)$ less for the 7-d frequency compared with the 2-d frequency (Table 2). New root dry weight was 2.3 times and 14.1 times greater $(P<$ 0.05 ) for plants irrigated every $2 \mathrm{~d}$ compared with plants irrigated every 4 or $7 \mathrm{~d}$, respectively. Similar results were found for total root dry weight with production among 2-d frequency plants increasing $(P<0.05)$ by $63 \%$ and $147 \%$ versus $4-$ and $7-d$ frequencies, respectively (Table 2). Viburnum odorotissimum irrigated every $2 \mathrm{~d}$ increased $(P<0.05)$ root lengths by 1.3 - and 2.8 -fold versus 4- and 7-d treatments, respectively (Table 1). Pour et al. (2005) reported leaf, stem, and root biomass of Pistasia vera L. decreased with increasing irrigation intervals. Similar results were reported for Acer nigrum Michx., Acer saccharum Marsh., and Coffea arabica L. (Azevedo et al., 2002; Graves, 1994).

Water potentials. Cumulative water stress (S $\psi)$ of I. cornuta 'Burfordii Nana' was affected $(P<0.05)$ by an irrigation frequency $\times$ stress day interaction (Fig. 1) with S $\psi$ ranging from 2.4 to $20.4 \mathrm{MPa} \cdot \mathrm{h}$. On the day before irrigation (stressed), S $\psi$ (Fig. 1) was greater and predawn $\Psi$ (data not shown) more negative for plants irrigated every $7 \mathrm{~d}$ at 8 and 12 WAT. Plant stress declined (i.e., $\mathrm{S}_{\Psi}$ was less and predawn $\Psi$ became less negative) on the stressed day as irrigation frequency increased $(P<0.05)$. On the day of irrigation (unstressed), plants were less stressed $(P<0.05)$ in comparison with the previous stressed day, and there were no differences $(P>0.05)$ among irrigation frequencies for all measurement dates. Only plants irrigated every $7 \mathrm{~d}$ on the day before irrigation had higher $(P<0.05) \mathrm{S} \psi$ at 16 WAT. There were no differences in $\mathrm{S} \psi$ by week $24(P>0.05)$. Similar trends were observed for both midday ( $\left.\Psi_{\text {midday }}\right)$ and dusk ( $\left.\Psi_{\text {dusk }}\right)$ water potentials (data not shown).

Irrigation frequency had no affect on $P$. tobira 'Variegata' water potential, and interactions with stress day were nonsignificant $(P>0.05)$. However, predawn $\Psi$ and $\mathrm{S} \psi$ (Table 3 ) and $\Psi_{\text {midday }}$ and $\Psi_{\text {dusk }}$ (data not shown) of $P$. tobira 'Variegata' were affected $(P<0.05)$ by stress day through 12 WAT.

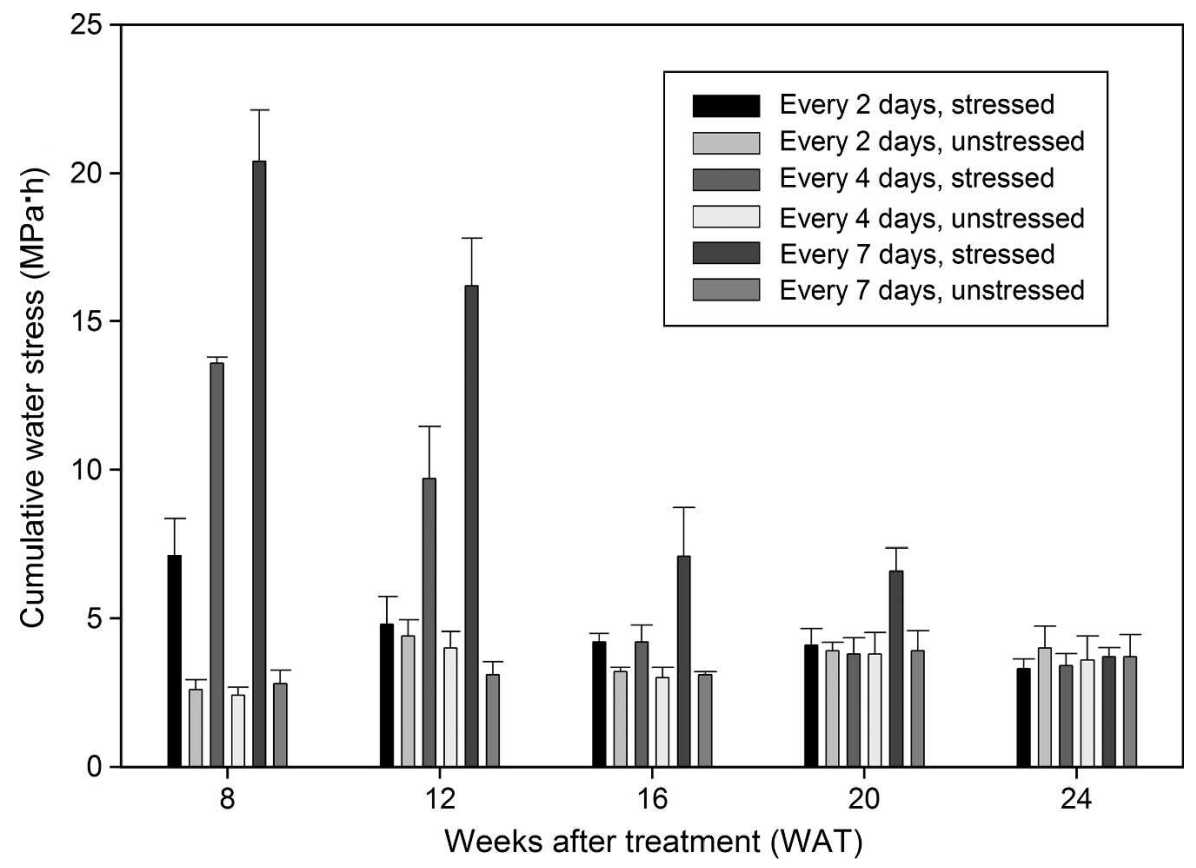

Fig. 1. Cumulative daily water stress integrals $(\mathrm{S} \psi)$ calculated monthly on the day before irrigation (stressed) and irrigation day (unstressed) for Ilex cornuta 'Burford Nana' irrigated with three frequencies $(2,4$, or $7 \mathrm{~d}$ ) over a 6 -month period during late summer to early spring in central Florida. Each bar represents the mean of four shrubs, whereas the vertical lines represent the SE.

Water stress was always greater $(P<0.05)$ on the day before irrigation than on the day of irrigation. By week 16, $\Psi_{\text {predawn }}, \Psi_{\text {midday }}$, $\Psi_{\text {dusk }}$, and S $\psi$ stress levels were similar among irrigation frequencies $(P>0.05)$. However, at week 24, S $\psi$ was again higher $(P<0.05)$ on the day before irrigation compared with irrigation day (Table 4). This may be attributed to new shoot growth flushes that likely altered shoot-to-root ratios. Rapid shoot to root balancing is essential to prevent water stress (Beeson, 1992; Gilman et al., 1998; Montague et al., 2000).

Among $V$. odorotissimum plants, predawn $\Psi$ became less negative $(P<0.05)$ on irrigation day (unstressed) compared with the day before irrigation (stressed) at 8 and 12 WAT (Table 4). Similar results occurred for $\mathrm{S} \psi$ at $12 \mathrm{WAT}$. An irrigation frequency $\times$ stress day interaction occurred at 8 WAT with lower $(P<0.05)$ S $\psi$ on irrigation day (data not shown). Values ranged from 13.3 to 2.6 $\mathrm{MPa} \cdot \mathrm{h}$ and were lowest among plants irrigated every $2 \mathrm{~d}$ on irrigation day. By week
16 , treatment, stress day, and irrigation frequency $\times$ stress level day effects were nonsignificant $(P>0.05)$ for $\Psi_{\text {predawn }}, \Psi_{\text {midday }}$, $\Psi_{\text {dusk }}$, and $S \psi$ with the exception of a midday stress day effect at week 20 (data not shown). When stress day effects were significant, water stress was greater the day before irrigation.

$\mathrm{G}_{S}$. On irrigation day for I. cornuta 'Burfordii Nana', $g_{s}$ increased compared with the day before irrigation at 8 and 12 WAT (Table 3 ). Irrigation frequency only affected $\mathrm{g}_{\mathrm{s}}$ at 12 WAT with greater mean $\mathrm{g}_{\mathrm{s}}$ within the 2-d treatment compared with 4- and 7-d treatments. Mean $g_{s}$ was significantly higher within the 4-d treatment compared with the $7-\mathrm{d}$ treatment. Interactions were nonsignificant $(P>0.05)$ and no differences for any parameter were evident by week 16 .

Treatment and stress day effects $(P<$ $0.05)$ on $g_{s}$ were found for P. tobira 'Variegata' at 8,12 , and 20 WAT (Table 3 ). $G_{\mathrm{S}}$ was directly proportional to irrigation frequency for all treatments with mean $g_{s}$ declining 
Table 3. Mean daily $g_{\mathrm{S}}\left(\mathrm{g}_{\mathrm{s}}\right)$ recorded monthly on the day before irrigation (stressed) and irrigation day (unstressed) for shrub species irrigated every 2,4 , or $7 \mathrm{~d}$ over a 6-month period during late summer to early spring in central Florida.

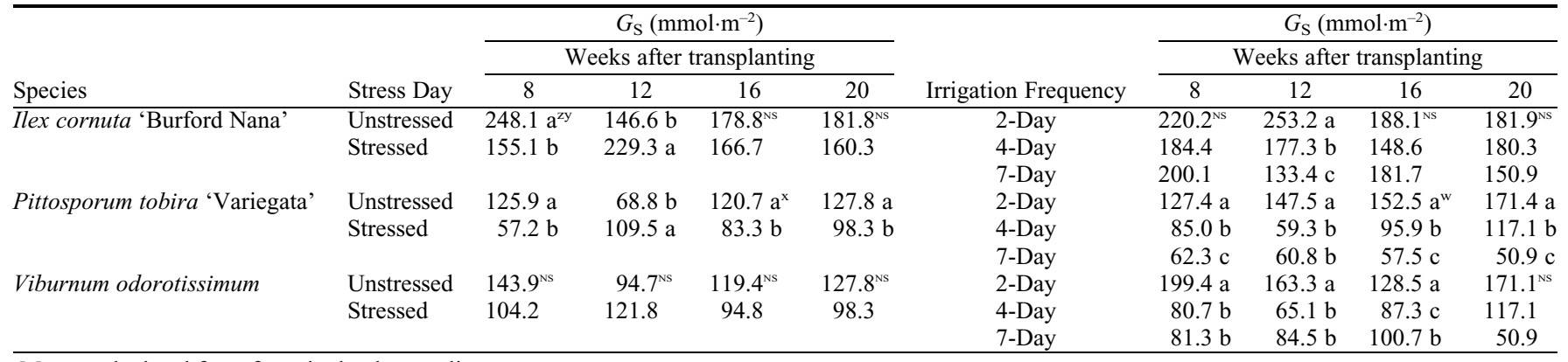

${ }^{\mathrm{z}}$ Means calculated from four single plant replicates.

${ }^{y}$ Mean separations within columns and species using Fisher protected LSD $(P<0.05)$.

${ }^{x}$ Values represent pooled $\mathrm{g}_{\mathrm{s}}$ irrigation frequency treatment means on the stressed and unstressed days; however, stress day effect cannot be clearly identified due to a significant irrigation frequency $\times$ stress day interaction, $P<0.05$.

${ }^{x}$ Values represent pooled $g_{s}$ stress day means for each irrigation frequency treatment; however, irrigation frequency effect cannot be clearly identified as a result of a significant irrigation frequency $\times$ stress day interaction $(P<0.05)$.

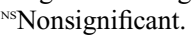

Table 4. Cumulative daily water stress integrals ( $\mathrm{S} \psi$ ) calculated monthly on the day before irrigation (stressed) and irrigation day (unstressed) for shrub species irrigated every 2,4 , or $7 \mathrm{~d}$ over a 6 -month period during late summer to early spring in central Florida.

\begin{tabular}{|c|c|c|c|c|c|c|c|c|c|c|c|c|}
\hline \multirow{2}{*}{ Species } & \multirow{2}{*}{ Stress Day } & \multicolumn{5}{|c|}{ Predawn $\Psi(\mathrm{MPa})$} & \multirow{2}{*}{ Stress Day } & \multicolumn{5}{|c|}{ Cumulative water potential, $\mathrm{S} \psi\left(\mathrm{MPa} \cdot \mathrm{h}^{-1}\right)$} \\
\hline & & \multicolumn{5}{|c|}{ Weeks after transplanting } & & \multicolumn{5}{|c|}{ Weeks after transplanting } \\
\hline$\frac{1}{\text { Pittosporum tobira 'Variegata' }}$ & Unstressed & $0.16 b^{z y}$ & $0.05 \mathrm{~b}$ & $0.15^{\mathrm{Ns}}$ & $0.22^{\mathrm{Ns}}$ & $0.18^{\mathrm{Ns}}$ & Unstressed & $2.71 \mathrm{~b}$ & $2.29 \mathrm{~b}$ & $4.04^{\mathrm{NS}}$ & $4.48^{\mathrm{NS}}$ & $4.89 \mathrm{~b}$ \\
\hline \multirow[t]{2}{*}{ Viburnum odorotissimum } & Unstressed & $0.20 \mathrm{~b}$ & $0.07 \mathrm{~b}$ & $0.17^{\mathrm{Ns}}$ & $0.09^{\mathrm{Ns}}$ & $0.06^{\mathrm{Ns}}$ & Unstressed & $2.95 \mathrm{~b}^{\mathrm{x}}$ & $3.89 \mathrm{~b}$ & $3.06^{\mathrm{Ns}}$ & $4.15^{\mathrm{Ns}}$ & $3.66^{\mathrm{Ns}}$ \\
\hline & Stressed & $0.36 \mathrm{a}$ & $0.24 \mathrm{a}$ & 0.12 & 0.09 & 0.07 & Stressed & $10.38 \mathrm{a}$ & $8.94 \mathrm{a}$ & 5.95 & 5.58 & 3.93 \\
\hline
\end{tabular}

${ }^{\mathrm{z}}$ Means calculated from four single plant replicates.

${ }^{\mathrm{y}}$ Mean separations within columns and species using Fisher protected LSD $(P<0.05)$.

${ }^{x}$ Values represent pooled S $\psi$ irrigation frequency treatment means on the stressed and unstressed days; however, stress day effect cannot be clearly identified as a result of a significant irrigation frequency $\times$ stress day interaction $(P<0.05)$.

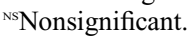

from 2 to $7 \mathrm{~d}$. On the day before irrigation (stressed), $\mathrm{g}_{\mathrm{s}}$ was less $(P<0.01)$ than on irrigation day (nonstressed) at weeks 8 and 20 ; however, at 12 WAT, $\mathrm{g}_{\mathrm{s}}$ was less on irrigation day. Lower mean $\mathrm{g}_{\mathrm{s}}$ values on irrigation day cannot be explained. Correlations between $g_{s}$ and environmental factors vapor pressure deficit, reference evapotranspiration, daily high temperature, relative humidity, and total daily solar radiation were nonsignificant $(P>0.05$; data not shown). Despite a treatment $\times$ stress day interaction at 16 WAT (Table 3 ), mean $\mathrm{g}_{\mathrm{s}}$ was highest $(P<$ 0.05 ) for the 2-d frequency on the day of irrigation and lowest for the 7-d frequency the day before irrigation with mean $\mathrm{g}_{\mathrm{s}}$ ranging from 188.8 to $53.1 \mathrm{mmol} \cdot \mathrm{m}^{-2}$, respectively (data not shown).

Viburnum odorotissimum irrigated every $2 \mathrm{~d}$ had higher $(P<0.05)$ mean $\mathrm{g}_{\mathrm{s}}$ than those irrigated every 4 and $7 \mathrm{~d}$ at 8,12 , and 16 WAT (Table 3$)$. No differences $(P>0.05)$ in mean $g_{s}$ were found between 4- and 7-d frequencies with the exception of week 16 . By 20 WAT, irrigation frequency effects were nonsignificant $(P>0.05)$. Throughout the experiment, no effects $(P>0.05)$ resulting from stress day were found, and there were no interactions between irrigation frequency and stress day. Similar results have been reported for both herbaceous and woody ornamentals (Chu et al., 1995; Jaimez et al., 1999; Tripepi et al., 1991). Tripepi et al. (1991) found daily irrigation increased $\mathrm{g}_{\mathrm{s}}$ among Betula pendula Roth seedlings compared with 3- or 5-d irrigation frequencies.

Numerous methods for determining establishment can be found in the literature. Beeson (1994) considered Quercus virginiana Mill. established when differences between predawn and dusk potentials were within $0.1 \mathrm{MPa}$ on irrigation day. No such trends were identified in the current study. Comparisons of predawn $\Psi$ between transplanted and established controls were used as an establishment measure for Acer platanoides L. 'Schwedleri' and Tilia cordata Mill. 'Greenspire' (Montague et al., 2000). Beeson and Gilman (1992) state S $\psi$ is a more sensitive measure of diurnal water stress than predawn $\Psi$ and compared S $\psi$ between transplanted and established plants of $Q$. virginiana (Beeson, 1994) and Pinus elliottii Engelm. (Beeson and Gilman, 1992). However, we found both measures were comparable estimates of shrub establishment. S $\psi$ differences between transplanted and established indicator plants were nonsignificant $(P>0.05)$ by 20,16 , and 16 WAT, respectively, for $I$. cornuta 'Burfordii Nana', P. tobira 'Variegata', and V. odorotissimum (data not shown). Predawn $\Psi$ were similar at 16 WAT for all species (data not shown). In the current study, water potentials between stressed and unstressed plants were also nonsignificant at 16 WAT for all species with the exception of $I$. cornuta 'Burfordii Nana' irrigated every $7 \mathrm{~d}$ on the day before irriga- tion (stressed). We found comparisons between stressed (nonirrigated) and unstressed (irrigated) plants is a new method for estimating establishment. This measure of establishment correlated with our estimates of establishment using comparisons of stress between transplanted and established plants, a technique well documented in the literature (Beeson, 1994; Beeson and Gilman, 1992; Montague et al., 2000).

Ilex cornuta 'Burfordii Nana' transplants were established within 16 to 20 WAT whether irrigated every 2 or $4 \mathrm{~d}$. Irrigating shrubs every fourth day instead of every second day resulted in a $100 \%$ reduction in irrigation volume applied with equivalent growth. Although establishment was delayed by 1 to 2 months if plants were irrigated every $7 \mathrm{~d}$, growth was not reduced compared with irrigating every 2 or every $4 \mathrm{~d}$.

Similar results were found for $V$. odorotissimum and $P$. tobira 'Variegata', except irrigation frequency had no effect on establishment time. Plants were established by 16 WAT, but differences in irrigation volume applied were significant $(P<0.0001)$ with 2-, 4-, and 7-d treatments receiving 826.6, 424.7, and 249.3 L, respectively. Unlike I. cornuta 'Burfordii Nana', growth and aesthetic quality were reduced as the interval between irrigations increased. Our protocol was not designed to determine whether this was incited by irrigation frequency or volume. Viburnum odorotissimum 
Table 5. Plant quality ${ }^{z}$ for Viburnum odorotissimum irrigated every 2, 4, or $7 \mathrm{~d}$.

\begin{tabular}{lcccccc}
\hline & \multicolumn{5}{c}{ Weeks after transplanting } \\
\cline { 2 - 7 } Irrigation frequency & \multicolumn{1}{c}{4} & 8 & 12 & 16 & 20 & 24 \\
\hline 2-day & $4.4 \mathrm{a}$ & $3.8 \mathrm{a} \mathrm{a}^{\mathrm{y}, \mathrm{x}}$ & $4.5 \mathrm{a}$ & $4.6 \mathrm{a}$ & $4.3 \mathrm{a}$ & $4.2 \mathrm{a}$ \\
4-day & $3.5 \mathrm{~b}$ & $3.3 \mathrm{ab}$ & $3.6 \mathrm{a}$ & $3.2 \mathrm{a}$ & $3.2 \mathrm{a}$ & $3.3 \mathrm{a}$ \\
7-day & $1.8 \mathrm{c}$ & $1.8 \mathrm{~b}$ & $1.5 \mathrm{~b}$ & $1.5 \mathrm{~b}$ & $1.5 \mathrm{~b}$ & $1.5 \mathrm{~b}$ \\
$P$ value & 0.0002 & $<0.05$ & 0.0075 & 0.0044 & 0.008 & 0.0075 \\
\hline
\end{tabular}

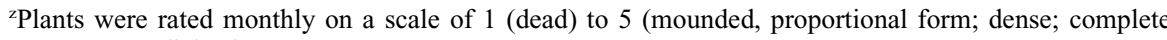
coverage, no dieback).

${ }^{\mathrm{y}}$ Means calculated from four single plant replicates.

${ }^{\mathrm{x}}$ Mean separations within columns using Fisher protected LSD $(P<0.05)$.

irrigated every $2 \mathrm{~d}$ had greater root growth (i.e., mass and length) compared with other irrigation frequencies, and shoot growth and aesthetic quality was reduced $(P<0.05)$ on plants irrigated every $7 \mathrm{~d}$ (Table 5). Furthermore, $50 \%$ of $V$. odorotissimum irrigated every $7 \mathrm{~d}$ died. Irrigating $P$. tobira 'Variegata' every $2 \mathrm{~d}$ increased leaf area, shoot dry weight, biomass, growth index, and root length relative to 4 - and 7-d treatments. Differences in growth are associated with higher $g_{s}$ rates for plants irrigated every $2 \mathrm{~d}$. Reductions in $\mathrm{g}_{\mathrm{s}}$ in response to water stress have been reported for numerous herbaceous and woody species as an avoidance mechanism to reduce desiccation and conserve water; however, photosynthesis (Pn) declines and growth is reduced (Clark and Hiler, 1973; Kramer, 1987; Montague et al., 2000; Syros et al., 2004). Reductions in growth in response to declines in $\mathrm{g}_{\mathrm{s}}$ have been reported for $A$. platanoides 'Schwedleri' and T. cordata 'Greenspire'. Montague et al., (2000) found $\mathrm{g}_{\mathrm{s}}$ declined by 1.5 to 13 times for transplanted $A$. platanoides 'Schwedleri' trees compared with nontransplanted control trees; values ranged from 1.3 to 19.5 times for T. cordata 'Greenspire'. Consequently, Pn declined during the first growing season and stem area, shoot elongation, leaf size, and total leaf area were significantly reduced among transplanted trees (Montague et al., 2000).

Data indicate that regardless of species, an irrigation frequency of every $4 \mathrm{~d}$ is sufficient for establishment within 16 weeks after transplanting. However, growth of $V$. odorotissimum and $P$. tobira 'Variegata' can be enhanced by more frequent irrigation. It must be noted the current study was conducted in a rainout structure to simulate maximum stress conditions and effect of rainfall events could decrease establishment times or increase growth rates.

\section{Literature Cited}

Archer, M. 2002. We must heed scary warnings about aquifer. Orlando Sentinel. 17 Feb: A1.
Azevedo, T.L., A. Bertonha, A.C.A. Goncalves, P.S.L. Freitas, R. Rezende, and J.A. Frizzone. 2002. Levels of superabsorbent polymer, irrigation interval and coffee plant growth. Acta Scientiarum. 24:1239-1243.

Barnett, D. 1986. Root growth and water use by newly transplanted woody landscape plants. The Public Garden. 1:23-25.

Beeson, R.C. 1992. Restricting overhead irrigation to dawn limits growth in container-grown woody ornamentals. HortScience 27:996999.

Beeson, R.C. 1994. Water relations of field-grown Quercus virginiana Mill. from preharvest through containerization and 1 year into a landscape. J. Amer. Soc. Hort. Sci. 119:169174.

Beeson, R.C. 2000. Classifying landscape ornamental species into water use groups using coefficients of water use efficiency. Final Research Report. Southwest Florida Water Management District. Proj. ID P67996CON000018.

Beeson, R.C. and E.F. Gilman. 1992. Diurnal water stress during landscape establishment of slash pine differs among three production methods. J. Arboricult. 18:281-287.

Bryla, D.R., T.J. Trout, J.E. Ayars, and R.S. Johnson. 2003. Growth and production of young peach trees irrigated by furrow, microjet, surface drip, and subsurface drip systems. HortScience 38:1112-1116.

Chu, C.C., T.J. Henneberry, and J.W. Radin. 1995. Effect of irrigation frequency on cotton yield in short-season production systems. Crop Sci. 35:1069-1073.

Clark, R.N. and E.A. Hiler. 1973. Plant measurements as indicators of crop water deficit. Crop Sci. 13:466-469.

Garcia-Navarro, M.C., R.Y. Evans, and R.S. Montserrat. 2004. Estimation of relative water use among ornamental landscape species. Sci. Hort. 99:163-174.

Gilman, E.F., R.J. Black, and B. Dehgan. 1998. Irrigation volume and frequency and tree size affect establishment rate. J. Arboricult. 24: $1-9$.

Gilman, E.F., T.H. Yeager, and D. Weigle. 1996. Fertilizer, irrigation, and root ball slicing affects burford holly growth after planting. J. Environ. Hort. 14:105-110.

Graves, W.R. 1994. Seedling development of sugar maple and black maple irrigated at various frequencies. HortScience 29:1292-1294.
Haman, D.Z., A. Smaljstra, and D. Pitt. 1996. Uniformity of sprinkler and microirrigation systems for nurseries. Fla. Coop. Extension Service Bulletin 321. IFAS, Univ. of Fla.

Henley, R., T.H. Yeager, and R.C. Beeson. 2000. Opinions on plant irrigation requirements. Univ. of Fla. IFAS. ENH 148.

Jaimez, R.E., F. Rada, and C. Garcia-Nunez. 1999. The effect of irrigation frequency on water and carbon relations in three cultivars of sweet pepper (Capsicum chinese Jacq.), in a tropical semiarid region. Scientia Hort. 81:301-308.

Kramer, P.J. 1987. The role of water stress in tree growth. J. Arboricult. 13:33-38.

Marshall, M. and E.F. Gilman. 2002. Effects of nursery container type on root growth and landscape establishment of Acer rubrum L. J. Environ. Hort. 16:55-59.

Montague, T., R. Kjelgren, and L. Rupp. 2000. Gas exchange and growth of two transplanted, fieldgrown tree species in an arid climate. HortScience 35:763-768.

Paine, T.D., C.C. Hanlon, D.R. Pittenger, D.M. Ferrin, and M.K. Malinoski. 1992. Consequences of water and nitrogen management on growth and aesthetic quality of drought-tolerant woody landscape plants. J. Environ. Hort. 10:94-99.

Pour, A.T., A.R. Sepaskhah, and M. Maftoun. 2005. Plant water relations and seedling growth of three pistachio cultivars as influenced by irrigation frequency and applied potassium. J. Plant Nutr. 28:1413-1425.

Salamone, D. 2002. A drying oasis series: Florida water crisis chapter 1. Orlando Sentinel. 03 Mar: A1.

SAS Institute. 1990. SAS user's guide: Statistics 6th ed. SAS Inst., Cary, N.C.

Schulze, E.D., A.E. Hall, O.L. Lange, M. Evenari, L. Kappen, and U. Buschbom. 1980. Long-term effects of drought on wild and cultivated plants in the Negev desert. I. Maximal rates of net photosynthesis. Oecologia 45:11-18.

Snedecor, G.W. and W.G. Cochran. 1980. Statistical methods. 7th ed. The Iowa State Univ. Press, Ames.

Syros, T., T. Yupsanis, M. Omirou, and A. Ecomomou. 2004. Photosynthetic response and peroxidases in relation to water and nutrient deficiency in gerbera. Environ. Exp. Bot. 52:23-31.

Thayer, R.L. 1982. Public response to waterconserving landscapes. HortScience 17:562565.

Trenholm, L.E., E.F. Gilman, G.W. Knox, and R.J. Black. 2002. Fertilization and irrigation needs for Florida lawns and landscapes. Univ. of Fla. IFAS. ENH 860.

Tripepi, R.R., M.W. George, R.K. Dumroese, and D.L. Wenny. 1991. Birch seedling response to irrigation frequency and a hydrophilic polymer amendment in a container medium. J. Environ. Hort. 9:119-123.

Watson, G.W. 1985. Tree size affects root regeneration and top growth after transplanting. J. Arboricult. 11:37-40. 